\title{
NAZARIYYAT
}

\section{A New Take on Semantics, Syntax, and the Copula: Note on Qutb al-Din al-Razi al-Tahtani's Analysis of Atomic Propositions in the Lawāmi" al-asrār}

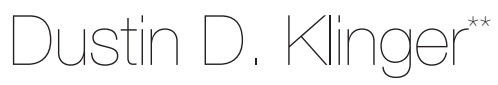

\begin{abstract}
In logic, Quțb al-Dīn al-Razī was broadly an orthodox Avicennan. However, in his enormously influential commentary on al-Urmawì’s logic handbook Mațâli al-anwār, he explicitly criticizes Avicenna and advances a novel analysis of atomic propositions. As a later addition that only survives in two manuscripts shows, Quțb al-Din was troubled by traditional accounts of the syntax and semantics of atomic propositions. For him, the main problem was a confused understanding of the copula. In atomic propositions of the form "A is B," the copula is the word that indicates that B is predicated of A ("is" in English, "esti" in Greek, but not usually expressed in Arabic). Avicenna had maintained, for lack of an Arabic equivalent to Aristotle's "esti," that the Arabic pronoun "huwa" should be used to form complete atomic propositions (e.g., "Jìm huwa $\left.b \vec{a}^{\prime \prime}\right)$. Quțb al-Din considers this to be mistaken on several levels. To straighten out the mistake, he disambiguates the predicative nexus of a proposition from its judgment, formulates a unified notion of unsaturatedness for predicates, and gives an account of the judgment-nexus. An upshot of this novel analysis is a reinterpretation of the Aristotelian distinction between secundum adiacens and tertium adiacens propositions.
\end{abstract}

Keywords: Quțb al-Dīn al-Rāzī al-Taḥtānī, Lawāmi al-asrār, Arabic Logic, Predication, hạml, Copula, Syntax, Semantics, Atomic Proposition.

* I would like to thank the organizers and participants of the Arché Workshop on the History of Arabic Logic, held at the University of St. Andrews in Scotland on May 8-9, 2019, for their valuable criticism and input upon the presentation of some of this material.

** PhD Candidate, Department of Near Eastern Languages and Civilizations/Department of Philosophy, Harvard University, Correspondence: dustinklinger@g.harvard.edu. 


\section{Introduction}

I

n modern logic, atomic propositions are expressed by $F(a)$. They are the simplest form of language use with which we make statements about the world that we take to be either true or false. In such statements we bring two ideas into a relation to form a new idea that either corresponds to a state of affairs or not. Atomic propositions are so called because they are the smallest unit of statements with a truth-value, and, if we were to break them up, what would remain would no longer be true or false. They are of course not, strictly speaking, "atomic" in themselves, for they consist of parts. In traditional logic, these parts are called "subject" and "predicate," connected by a copula ("is" in "S is P"). Roughly, in order to explain what transforms a list of words ("Socrates, wise") into a statement with a truth-value ("Socrates is wise"), we need to give an account of what this unifying force of the copula is.

The question of what atomic propositions are philosophically speaking, and how it is that we may use them to make true or false statements about the world, has been a core problem in the analytic tradition of philosophy. In 1900, Bertrand Russell wrote at the beginning of his book on Leibniz: "That all sound philosophy should begin with an analysis of propositions, is a truth too evident, perhaps, to demand a proof." ${ }^{1}$ Donald Davidson, in Truth and Predication (2005), still proclaimed that "it is just this unity [of the proposition] that a theory of predication must explain. The philosophy of language lacks its most important chapter without such a theory; the philosophy of mind is missing a crucial first step if it cannot describe the nature of judgment; and it is woeful if metaphysics cannot say how a substance is related to its attributes."

There is a long and multifaceted history of thinking about the analysis of atomic propositions, or simple categorical statements, as they are called in the Aristotelian traditions. ${ }^{3}$ Part of this history unfolded in the commentary tradition

1 Bertrand Russell, A critical exposition of the philosophy of Leibniz, 3rd ed. (Wolfeboro, NH: Longwood Press, 1989), 8.

2 Donald Davidson, Truth and predication (Cambridge, MA: Harvard University Press, 2005), 77. For a comprehensive treatment of this problem in analytic philosophy, both historical and systematic, see Richard Gaskin, The unity of the proposition (Oxford; New York: Oxford University Press, 2008).

3 For clarity's sake, I shall mostly use "atomic propositions" rather than literal translations like "categorical statements" or "predicative propositions," because what I am interested in here are the simplest forms of statements with a truth-value as opposed to compound statements with a truthvalue that may be taken to be categorical or predicative as well. 
Dustin D. Klinger, A New Take on Semantics, Syntax, and the Copula:

Note on Qutb al-Din al-Razi al-Tahtani's Analysis of Atomic Propositions in the Lawāmi' al-asrār

on Aristotle's - and later Avicenna's - logical works and was mainly written in Greek, Syriac, Arabic, and Persian. This history has remained almost entirely unknown to analytic philosophers and intellectual historians alike. ${ }^{4}$ However, it is a history remarkable for the fact that Semitic languages, just like Frege's mathematical notation $F(a)$, do not employ a copula. Hence, thinkers in the Arabic tradition were confronted with a mismatch between Aristotle's logical framework, developed from within the Greek language, and their own logico-linguistic intuitions from Arabic grammar. How they dealt with this may offer valuable insights when compared with the concern of analytic philosophers working in Frege's wake, who himself was convinced that the disparity between natural language and his Begriffsschrift brought out, in a logically conspicuous fashion, an ambiguity of our language that had misled many in the history of philosophy. ${ }^{5}$ from ancient Greek to humanist thinkers in the Latinate tradition are Gabriël Nuchelmans, Theories of the proposition. Ancient and medieval conceptions of the bearers of truth and falsity, North-Holland linguistic series, v 8 (Amsterdam: North-Holland Pub. Co., 1973 and Late-scholastic and humanist theories of the proposition, Verhandelingen der Koninklijke Nederlandse Akademie van Wetenschappen, Afd Letterkunde (Amsterdam; New York: North Holland Pub. Co., 1980). As far as I know, nothing comparable exists for the Arabic tradition, especially not for the post-Avicennan period. On that period, some of the more recent contributions to the literature on the analysis of atomic propositions are Khaled El-Rouayheb, "Does a Proposition Have Three Parts or Four? A Debate in Later Arabic Logic," Oriens 44, no. 3-4 (2016); "Dashtakī (d. 1498) and Dawānī (d. 1502) on the Analysis of Existential Propositions," Oriens 47, no. 3-4 (2019). Asad Q. Ahmed, "Interpreting Avicenna: Urmawi/Tahtani and the Later Logical Tradition on Propositions." Documenti e studi sulla tradizione filosofica medievale 21 (2010) discusses the truth conditions of propositions. On the history of the paradox of the "absolute unknown" (al-majhūl al-muțlaq) and related problems with predication in atomic propositions, see Joep Lameer, "Ghayr al-ma'lūm yamtani' al-h̆ukm 'alayhi," Oriens 42 (2014). On the classical period up to Avicenna, many studies broach the subject, though none of them are systematic historical studies focusing, like Nuchelmans', on the logical analysis of propositions. The following, with bibliographies, may serve to indicate the state of research: Fadlou Shehadi, Metaphysics in Islamic philosophy (Delmar, NY: Caravan Books, 1982); Abdelali Elamrani-Jamal, Logique aristotélicienne et grammaire arabe: étude et documents, Études musulmanes (Paris: J. Vrin, 1983); "Verbe, copule, nom dérivé (fill, kalima, ism muštaqq) dans les commentaires arabes du Peri Hermeneias d'Aristote: avec un texte inédit d'Ibn Rušd," in Studies in the history of Arabic grammar II: proceedings of the 2nd Symposium on the History of Arabic Grammar, Nijmegen, 27 April-1 May 1987, ed. Kees Versteegh and Michael G. Carter (Amsterdam; Philadelphia: J. Benjamins Pub. Co. , 1990); Sadik Türker, "The Arabico-Islamic Background of alFārābī's Logic," History and Philosophy of Logic 28, no. 3 (2007); Stephen Menn, "al-Fārābī's Kitāb alhurüf and His Analysis of the Senses of Being," Arabic Sciences and Philosophy 18, no. 1 (2008); Saloua Chatti, "Syncategoremata in Arabic Logic, al-Fārābī and Avicenna," History and Philosophy of Logic 35, no. 2 (2014); Alexander Kalbarczyk, Predication and ontology: studies and texts on Avicennian and postAvicennian readings of Aristotle's Categories (Berlin; Boston: De Gruyter, 2018).

5 This was the overall project in Gottlob Frege, Begriffsschrift, eine der arithmetischen nachgebildete Formelsprache des reinen Denkens (Halle a. d. Saale: L. Nebert, 1879). See also, for example, "Über Begriff und Gegenstand," Vierteljahrsschrift für wissenschaftliche Philosophie 16, no. 2 (1892): 194. 
Quṭb al-Dīn al-Rāzī's unusual criticism of Avicenna in the Lawāmi' al-asrar is a forceful intervention addressing this fundamental problem in the Arabic logical tradition. In what follows, I wish to provide a preliminary note of his criticism of the traditional accounts of the analysis of atomic propositions and of how he proposed to make them coherent. Further studies will have to determine these arguments' relations to other writings of his, evaluate their reception history, and identify aspects that may be of interest to intellectual historians or philosophers of language.

\section{Some Background on Quṭb al-Dīn al-Rāzī, Categorical Statements (al-qaḍiyya al-ḥamliyya), and the Lawāmi" al-asrār}

Quṭb al-Dīn studied and worked in an environment in which "revisionist" Avicennism had gained considerable traction. ${ }^{6}$ Born and raised in late seventh/thirteenthcentury Warāmīn, the new Mongol administrative center in Rayy, he studied with and received an ijāza from Nașīr al-Dīn al-Ṭūsī's (d. 1274) star pupil, the Twelver Shīî̀ al-'Allāma al-Hillī (d. 1325). It is likely that they both travelled, studied, and taught in the "mobile school" (madrasa-ye sayyāra) that was part of the İlkhān Ūljāytū's (r. 1304-16) entourage on his expeditions. ${ }^{7}$ If that was indeed the case, then it is very likely that he also studied at the Marāgha observatory, with which both Athīr alDīn al-Abharī (d. 1264) and Najm al-Dīn al-Kātibī (d. 1276) were affiliated. ${ }^{8}$ In the mid-seventh/thirteenth century, this observatory was a hotspot for "revisionist" Avicennans against whom Quṭb al-Dīn may be seen to react.

Measured against the sheer amount of super-commentaries and glosses on his two monumental lemmatic commentaries on the new logical summae, al-Kātibī's Shamsiyya and Sirāj al-Dīn al-Urmawī’s (d. 1283) Mațāli al-anwar, Quṭb al-Dīn was arguably the most influential Arabic logician of the eighth/fourteenth century. ${ }^{9}$ The

6 Tony Street coined the term "revisionist Avicennan" to refer to logicians who took their departure from Avicenna's texts but critically engaged and amended his logical system. For the use of the term and a brief historic aperçu, see Khaled El-Rouayheb, "Arabic Logic after Avicenna," in The Cambridge companion to medieval logic, ed. Catarina Dutilh Novaes and Stephen Read (Cambridge: Cambridge University Press, 2016), 69.

7 Ahmed H. Al-Rahim, The creation of philosophical tradition: biography and the reception of Avicenna's philosophy from the eleventh to the fourteenth century A.D. (Wiesbaden: Harrassowitz Verlag, 2018), 131.

8 Ibid., 132.

9 For a list of super-commentaries and glosses on these works, see Robert Wisnovsky, "The Nature and Scope of Arabic Philosophical Commentary in Post-Classical (ca. 1100-1900) Islamic Intellectual History: Some Preliminary Observations," Bulletin of the Institute of Classical Studies 47 (2004): 165f.; cf. also Khaled El-Rouayheb, The development of Arabic logic (1200-1800) (Basel: Schwabe Verlag, 2019), 72. 
commentary on the work of al-Urmawī with which we are concerned, Lawämi' alasrär fi sharh Mațāli al-anwär, is roughly twice as long as that on the Shamsiyya and can thus be regarded as one of his most thorough and close textual engagements with the "revisionist" Avicennians. Overall, in this work as in others, Quṭb al-Din sought to rehabilitate Avicenna against his own immediate predecessors, believing that almost all the departures from "the Shaykh" proposed by "the author of alKashf [i.e. Afḍal al-Dīn al-Khūnajī (d. 1248)] and those who follow him" were illconsidered and based on misunderstandings. ${ }^{10}$

It is in this context that we should see the departures from Avicennan doctrine. Quṭb al-Dīn, it seems, would make all the effort necessary to extract a coherent presentation from a charitable reading of Avicenna; however, if such was eventually judged unfeasible, he would readily advance his own theory. The analysis of atomic propositions is a case in point. El-Rouayheb has suggested that Quṭb al-Dīn was the first in the tradition to hold that a proposition is to be analyzed as consisting of four parts, not three - subject, predicate, copula, and judgment (earlier logicians had not distinguished between copula and judgment) - a view that had been predominant for almost two centuries. ${ }^{11}$

Yet there is more to his dissatisfaction with the traditional accounts of atomic propositions than the number of their parts. From the text of the Lawämi al-asrār, it emerges that he also quibbled with various points regarding the semantics of simple utterances and the syntactic properties of the copula, all of which made him rethink the whole matter and insert, likely at a later date, his revised position on the analysis of atomic propositions. Before reconstructing this process, it will be helpful to provide some background.

Around Quțb al-Dīn's time Aristotle's Organon, including the early chapters of the De interpretatione and the beginning of the Analytica Priora, where single utterances and atomic propositions are treated respectively, had been translated, commented upon, and reorganized several times. Even though discussions on many points persisted, scholars in the logical tradition around this time can be said to have roughly agreed on the following outlines regarding the analysis of atomic propositions.

11 "Does a Proposition Have Three Parts or Four? A Debate in Later Arabic Logic." 
All declarative discourse consists of simple expressions. Simple expressions are sounds, no part of which is significant in isolation. A simple expression can be a verb (kalima), noun (ism), or auxiliary ('ad̄) , corresponding roughly, but by no means systematically, to what grammarians call fil, ism, and harf. A simple expression's type is determined by its semantic content: If it signifies a complete meaning and a time in its morphology, then it is a verb. If it does not signify a time but its meaning is complete (i.e., it names something), then it is a name. Otherwise, it is an auxiliary.

Verbs can either be real verbs (kalimāt haqiqiyya) that signify an event, a nexus to a subject, and a time for that nexus, or hyparctic ${ }^{12}$ verbs (kalimāt wujūdiyya) that only signify a nexus and a time for it. There is no agreement on how precisely hyparctic verbs like kāna, yūjad, and so on signify and how they are to be classified. Nouns are either semantically primary prototypes (al-amthila al-'ūlā) or names morphologically derived (al-asmä' al-mushtaqqa) from prototypes. The latter can only occur in the predicate place, because they signify a non-articulated subject in which the notion they signify is said to inhere (e.g., "walking" is a derived noun whose meaning implies a subject that does the walking). ${ }^{13}$ Everything else is an auxiliary. It is contested, however, whether or not the copula should be considered an auxiliary.

Categorical propositions are composites consisting of three simple parts: the meaning of the subject (mawdīi), the meaning of the predicate (mahmūl), and a nexus (nisba) between them signified by the copula (rābița) if expressed or considered implicit if not.

The copula may or may not be expressed in Arabic sentences to signify the nexus between subject and predicate. There had been, at least since Abū Nașr alFārābī's (d. 950) commentary on the De interpretatione, a strong feeling that Arabic was in some sense deficient in comparison to Aristotle's Greek, and that artificial

12 I take the translation "hyparctic verbs" for kalimāt wujūdiyya from Zimmermann, for the same reasons he chose to coin it: In the Arabic translations of Aristotle, in this context wujūdì was meant to render the notion of hyparchein, and "existential verbs" might be a misleading translation, for e.g. șāra (become) is also considered to be a hyparctic verb. See the introduction in Fritz W. Zimmermann, AlFarabi's commentary and short treatise on Aristotle's De interpretatione, Classical and medieval logic texts (London: Published for the British Academy by Oxford University Press, 1981), lx.

13 The theory of prototypes and derived nouns is first properly formulated in Abū Naṣr al-Fārābī’s (d. 950) commentary on the De interpretatione and seems to draw on a misreading of Aristotle's Categoriae and De anima combined with what al-Fārābī took to be universally valid features of Arabic grammar. See ibid., xxxii-xxxiv. Avicenna clearly read al-Fārābi on this and further developed the theory of derived nouns in a chapter (the only one that does not correspond to anything in Aristotle's De interpretatione) of his al-'ibāra in the Shifä': Abū 'Alī al-Husayn Ibn Sīnā, al-'Ibāra min Mantiq Kitāb al-Shifä', part 1, vol. 3 (Cairo: Dār al-Kātib al-'Arabī, 1970), 25-30. 
constructions were needed to exhibit a proposition's logical form on the level of language. ${ }^{14}$ Thus, scholars came to agree that the copula should be expressed, either as temporal with hyparctic verbs like "kāna" or "yūjad," or as non-temporal with "mawjūd" or "huwa."

Categorical propositions may be binary (thunä̉iyya) or ternary (thulāthiyya), depending on the use of the copula. Avicenna had classified categorical propositions into

a. complete ternary (thulāthiyya tāmma), when the a-temporal copula "huwa" is used, such as "Zayd huwa kātib,"

b. defective ternary (thulāthiyya nāqișa), when temporal copulae are used, such as "Zayd yakūnu kātib,"

c. and binary (thunä'iyya), when no copula is expressed, such as "Zayd yaktub" or "Zayd kätib."

This doctrine is a result of the difficulties presented by the Greco-Arabic translation process of Aristotle's De interpretatione 10. ${ }^{16}$ What Aristotle arguably had meant to distinguish were existential usages of the copula "einai" ("Socrates is [i.e. exists]"), where "einai" is added as a second element (secundum adiacens), from the predicative ones ("Socrates is wise"), where "einai" is added as a third element (tertium adiacens). ${ }^{17}$ This made little sense to the early Arabic commentators, and yet the received opinion by Quțb al-Dīn's time, even though questioned by alUrmawī, seems to have been Avicenna's.

Overall, the above outline concerning the analysis of atomic propositions is also roughly how al-Urmawi presents the matter in his Matāli' al-anwār. In his own commentary, Quṭb al-Dīn proceeds lemma by lemma, routinely engaging with his predecessors' arguments, whether they are mentioned by al-Urmawì or not. It

14 For al-Fārābī's "Hellenizing" Aristotelianism, see Zimmermann, Al-Farabi's commentary and short treatise on Aristotle's De interpretatione, cxxxvii-cxxxix.

15 Ibn Sīnā, al-'Ibāra min Mantiq Kitāb al-Shifä', 76-79.

16 See especially $19^{\mathrm{b}} 14-20^{\mathrm{a}} 15$, where assertions are classified into those that contain "einai" as a second element, or as a third element, or not at all. A recent critical edition improving on the Oxford Classical Text is Aristotle, De interpretatione = Peri hemēneias, ed. Hermann Weidemann (Berlin; Boston: De Gruyter, 2014). See also C. W. A. Whitaker, Aristotle's De interpretatione: contradiction and dialectic (Oxford, NY: Oxford University Press, 1996), 131-50.

17 For a diachronic history of this distinction up to the Latin Scholastics, see Gabriël Nuchelmans, Secundum/tertium adiacens: vicissitudes of a logical distinction, Verhandelingen der Koninklijke Nederlandse Akademie van Wetenschappen (Amsterdam; New York: North Holland Pub. Co., 1992). 
seems to me that Quț al-Dīn, after cursorily commenting on and criticizing alUrmawī's text, realized in retrospect that their positions, as well as his, did not add up to a coherent whole. Hence he reconsidered several of his positions, notably the definitions of the different types of single utterances, the semantics of the verb, the syntactic constraints within a proposition, and the analysis of the parts of the proposition. He then molded them into his own theory of atomic propositions that disagreed with both the "revisionist" Avicennans and with Avicenna himself.

In the Mațāit al-anwār, the above issues are treated in two places. Although the work itself is divided into Logic and Metaphysics, Quṭb al-Dīn only comments on the Logic, ${ }^{18}$ which is again sub-divided into the Acquisition of Conceptions and the Acquisition of Assents. This division reflects the new conception of the subject matter of logic introduced by al-Khūnajī. ${ }^{19}$ It was espoused by all authors of the great thirteenth-century logic handbooks, namely, al-Abharī, al-Kātibī, and alUrmawī. Quṭb al-Dīn himself, however, was highly skeptical of this and thought that the subject matter of logic was second intentions, as Avicenna had held. ${ }^{20}$

As was customary for logic manuals, the text starts with preliminaries on the need for logic (I 28-58) and its subject matter (I 60-85) and then deals with the

18 There are several editions of Quțb al-Dīn's commentary, the most recent being those by the Iranian scholars 'Alī Aṣghar Ja'farī Valanī and Abū al-Qāsim Raḥmānī, respectively: Quṭb al-Dīn al-Rāzī alTaḥtānī, Lawāmi' al-asrār fì sharḥ Mațāil' al-anwār, ed. 'Alī Aṣghar Ja'farī Valanī (Tehran: Dānishgāh-i Tihrān, 2014); Lawāmi“ al-asrār fì sharh Mațāli al-anwār, ed. Abū al-Qāsim Raḥmānī, 3 vols. (Tehran: Mu'assasah-i Pizhūhishī-i Hikmat va Falsafah-i İān, 2014). Raḥmānī's is the first edition with a thorough introduction and a useful critical apparatus; it is also the only edition I have seen that includes Quțb al-Dīn's later addition on atomic propositions. References will all be to Rahmmānī's edition indicating volume, page, and line (e.g., II 224.3).

19 It should be noted that in terms of the structure of logical works, such a conception is already foreshadowed by Avicenna's reorganization in the Ishärāt of the Aristotelian material around the notions of conception and assent (cf. Ahmad Hasnawi and Wilfrid Hodges. "Arabic Logic up to Avicenna." In The Cambridge Companion to Medieval Logic, edited by Catarina Dutilh Novaes and Stephen Read. Cambridge: Cambridge University Press, 2016, 7-8). We find the same structuring principles perpetuated by Fakhr al-Dīn al-Rāzì (d. 1210) in the Logic part of the Mulakhkhaș where he treats everything that traditionally had been treated in the Organon up to the beginning of the Analytica Posteriora under the headings "Fì kayfiyyat iqtināṣ al-tașawwurāt" and "Fì al-tașdīqāt." See Fakhr al-Dīn Muhammad ibn 'Umar al- Rāzī, Manțiq al-Mulakhkhaṣ (Tehran: Dānishgāh-i Imām Ṣādiq, $1381 \mathrm{AH}$ [2002/03]), ix, xiv.

20 For al-Khūnajī's place in the history of Arabic logic, see the introduction in Afḍal al-Dīn al- Khūnajī, Kashfal-asrār 'an ghawāmiḍ al-afkār, ed. Khaled El-Rouayheb (Tehran; Berlin: Mu'assasah-'i Pizhūhishī-i Hikmat va Falsafah-'i İrān; Mu’assasah-’i Muțāla'āt-i Islāmī-i Dānishgāh-i Āzād-i Birlīn, 2010). On the debates about the subject matter of logic, see Khaled El-Rouayheb, "Post-Avicennan Logicians on the Subject matter of Logic: Some Thirteenth- and Fourteenth-Century Discussions," Arabic Sciences and Philosophy 22, no. 1 (2012). 
semantics of linguistic expressions (I 87-148). Some of these parts (I 116-147) deal with the classification of simple expressions into name, verb, and auxiliary, roughly the same material as chapters 1-4 of Aristotle's De interpretatione. ${ }^{21}$ The second part on the Acquisition of Assents begins with compound expressions, namely, propositions (II 1-274), and covers similar ground as do the first chapters of the Analytica Priora. ${ }^{22}$ We shall look at these parts in turn.

\section{The Semantics of Simple Expressions (al-alfāza al-mufrada)}

In the first part on the semantics of simple expressions, Quṭ al-Dīn develops two thoughts that I think might have been among the reasons why he felt he had to revise his account of the analysis of atomic propositions in the second part. First, that hyparctic verbs form a distinct category of simple expressions and, second, that third person inflected verbs signify a nexus, but not a judgment, and hence have no truth-value. Both thoughts feed into his criticism of Avicenna, the quadripartite analysis of the parts of the proposition, and the formulation of a unified notion of unsaturatedness for predicates.

Concerning the first thought: Commenting on the first lemmata, where alUrmawī defines the different types of single utterances, Quṭb al-Dìn argues that an appropriate investigation (nazar șä'ib, I 126.8) demands that the types of simple expressions be divided into four as opposed to three, as al-Urmawì had presented. He intimates that he thinks this is also what we should understand when we read Avicenna carefully. For any simple expression (lafz mufrad)

a. either does or does not signify a complete meaning. If it does, then it either signifies a time as well, the meaning of which is one of the three tenses, and then it is a verb (kalima);

b. if it does not signify [time], then it is a name (ism);

c. and if it does not signify a complete meaning, then it either signifies time as well, in which case it is a hyparctic verb (kalima wujüdiyya),

d. or it does not, in which case it is an auxiliary ('adā) (I 126.9-12).

His point here is that if we distinguish the different types of simple expressions by the criteria of semantic completeness and the signification of time, then there

21 16 1-17 ${ }^{\mathrm{a}}$, in Aristotle, De interpretatione = Peri hemēneias.

22 Roughly chapters 1 and 2 in Analytica priora et posteriora, ed. W. D. Ross (Oxonii: E Typographeo Clarendoniano, 1964). 
is a class of expressions that has to be acknowledged as being a distinct type of simple expression, namely, the hyparctic verbs. This is so because while hyparctic verbs do signify time like normal verbs, by themselves they are not semantically complete and, in that respect, are just like auxiliaries. This is important, because this distinction had not previously been made explicit and logicians had been debating the use of hyparctic verbs as copulae. There is a more general importance to naming logical categories, especially when they have no equivalents in grammar (cf. I 127) that can make the logical syntax of a sentence conspicuous. In the second part, Qutb al-Dìn will use this distinction to develop the notion of hyparctic verbs as two-placed predicates.

Concerning the second thought: In the context of the discussion on the difficulties surrounding the definitions of the respective types of expressions, alUrmawī refers to Avicenna and mentions a problem arising from defining "verb" (kalima) as a simple expression (no part of which signifies anything in isolation, as we said) signifying a complete meaning and a time in which that meaning occurs. The problem raised by Avicenna in the Shifä' is whether an inflected verb is a complete categorical statement and thus has a truth-value or not. Quṭb alDīn explicates what al-Urmawī and al-Khūnajī report from Avicenna; however, in characteristic fashion, he says that their presentation has problems and that their transmission was faulty (wa naḥnu naqūl: fì al-manqūli ishkālun wa fì al-naqli ikhtilālun, I 132.7).

Avicenna is reported to have said in sum: Inflected present tense verbs may be verbs for the grammarians, but they cannot be for the logician, because they are composite, susceptible to truth and falsehood, and their augments (hamza, tā', $y \bar{a}$ ) add a meaning to their uninflected form (I 128.1-3). ${ }^{23}$ But this is misleading, claims Quṭb al-Dìn, because Avicenna also says: Not everything that the Arab [grammarians] call a verb ( $\left.f^{\prime} l\right)$ is a verb (kalima) for the logicians, for the inflected present tense verbs that are not in the third person, but in the first or second, are a $\operatorname{verb}\left(f^{c} l\right)$ for them, but not a verb (kalima) [for the logicians] (I 130.1-2). ${ }^{24}$

What is implied here, as opposed to al-Urmawì's summary, is that third person inflected verbs are verbs for both grammarians and logicians. Thus, Quṭb al-Dīn puts al-Urmawī on the spot for not having read his Avicenna carefully enough. From 
al-Urmawiss presentation, it would appear that Avicenna thought that because the augments related to the inflected verb somehow made all inflected verbs composites, they cannot be taken as simple utterances but must be considered complete statements with a truth-value. On this line of argumentation, it is hard to see how Avicenna could also hold that third person inflected verbs were, in fact, not statements with a truth-value, as the second quote suggests.

Quțb al-Dīn points out at some length what he thinks al-Khūnajī and alUrmawī had misunderstood and misrepresented; however, our investigation is only interested in how he suggests solving the problem of inflected verbs. If we take, as al-Urmawi points out (I 128-129), the augments of inflected verbs to add a meaning to the uninflected form in such a way that the expression becomes composite, then third person inflected verbs should also be composite. But composite statements have a truth-value. The only difference between "amsh" (I walk) and yamshī (he walks) is that the hamza signifies a determinate subject, whereas the $y \vec{a}$ ' signifies an indeterminate subject. In this case, the argument would be that yamshi really means that there is something that walks, that is to say $\exists(\mathrm{x}) \mathrm{M}(\mathrm{x})$, where $M$ stands for mashī (walking), and that certainly has a truth-value.

Quṭb al-Dīn now argues that yamshī, in fact, does not mean $\exists(\mathrm{x}) \mathrm{M}(\mathrm{x})$. Rather, yamshi by itself does not signify anything over and above the concept of walking and its nexus to an unspecified subject; it is therefore not composite. In that respect, it is exactly analogous to the mașdar (nomen actionis) "mashï" (walking), which signifies, by dint of its being an ism mushtaqq (derived noun), the action of walking and a non-articulated subject in which the walking inheres (I 134.6-11). ${ }^{25}$ What Quṭb al-Dīn is effectively distinguishing here is $\exists(x) M(x)$ and $M(x)$, where the former is indeed true if there is anything that walks, whereas the latter only receives a truthvalue once a value is assigned to the variable. The case is different with "amshî," because here a specified subject is signified over and above the signification of the concept of walking and the nexus to a subject. In other words, in uttering "amshī," the speaker already assigns a value to the variable, namely, himself (I 134.1-11), and thus any utterance of "amsh" is a composite statement. First and second person inflected verbs are thus to be considered complete statements with a truth-value, whereas third person inflected verbs (like derived names) are what I call, using Fregean terminology, inherently unsaturated because they signify that a certain action is linked to an unspecified subject. 
Both of these thoughts, the insistence that hyparctic verbs are - based on their semantic value - a distinct category of simple utterances, and the idea that third person inflected verbs (and derived names) are simple expressions that - based on their semantic value - are inherently unsaturated, come up again in the second part on the Acquisition of Assents in the context of discussions on the copula and the syntax of atomic propositions.

\section{The Parts of the Proposition (ajzā' al-qadiyya): The Copula (al-rābița), the Judgment Nexus (al-nisba al-hukmiyya), and the Syntax of Atomic Propositions}

The first chapter of the second part on the Acquisition of Assents deals with propositions proper as the smallest unit of which syllogisms are made up. After their preliminary classification into categorical and conditional propositions, alUrmawī discusses the parts of atomic propositions (II 15-42). In this part, Quṭ al-Din advances several novel claims. First, he argues that the proposition has four parts, with the copula signifying both the nexus of the predicate to the subject and the judgment that the predicate and subject are so connected. Second, he criticizes Avicenna for commending the use of "huwa" (he) as a non-temporal copula.

This, together with what he takes to be a misrepresentation of Avicenna's distinction between secundum and tertium adiacens propositions by al-Urmawī and al-Khūnajī, leads him, thirdly, to reconceptualize - in a later addition to the text - the role of the copula, harkening back to the two thoughts laid out above, as a marker of unsaturatedness in all predicates - be they hyparctic verbs, real verbs or nouns - which can be signified in different ways by simple expressions. In what follows, these steps are reconstructed with textual documentation.

It is noteworthy how Quṭb al-Dìn explains what atomic propositions are. He comments on the first lemma thus:

By "proposition" [al-Urmawī] means the categoric statement; for it is because of this that discourse [is able to] convey [anything at all]. [The proposition] is completed by that on which judgment is passed, which is the subject, and by that with which judgment is passed, which is the predicate; and the nexus connecting the predicate to the subject with a connection that is either affirmative or negative, and this is the judgment-nexus. The mere meaning of subject and predicate is not [yet] a proposition, for if the two are conjoined in the mind without judgment, [then] the result is not a proposition. [The proposition] is like extra-mental composites, and its parts [are] like their parts, because its terms [i.e., subject and predicate] are like matter insofar as the proposition is with 
them in potentiality - just as the matter of the bed is in that way. And the judgment between the two is like the form, for it obtains in actuality with it and the two terms. Like with the form of the bed, the two terms together with the judgment are like matter and form, for these two precede [the judgment], just as the [matter of the bed] is to [its form]. The two [terms] are material parts, and the judgment is a formal part.

It is well known that [the judgment] is the strongest part and that it is intrinsic to [any] consideration (itibär). It is that which affirms or negates, makes true or false, and the judgments and implications of [the proposition] depend on it [alone]. If I want to make evident with an expression what is otherwise hidden, then the most appropriate thing is to indicate it [i.e., the judgment] with an expression, and that expression is called a "copula" (rābița). (II 16.6-17.3)

Nothing of this analogy of the form and matter of a bed is found in al-Urmawìs main text, and it is striking that Quṭb al-Din uses it. Taking the judgment to be analogous to the form in a hylomorphic compound explains why he puts such emphasis on the judgment and would want to dissociate the judgment-nexus from the mere linking of two terms in the mind and thus make the parts of the proposition four. ${ }^{26}$ He goes on to expound precisely this quadripartite analysis of the proposition, countering a possible objection:

But it might be said: The parts of the proposition, when analyzed, are four, namely, the subject, the predicate, the nexus between them, and the judgment, that is: the obtaining or not of the nexus. If, then, that which is signified by the copula is the nexus, then inevitably there must be another expression for the judgment, so that the expressions correspond to the meanings.

[...] Then we say: That which signifies the judgment [also] signifies the nexus, and there is no need for signifying it with another expression. As for the expression "huwa" (he), it is the affirmative copula, just as they express the negational copula independently of it with a negational particle. Then, the copula either leaves a support for the mind to conceive its meaning, and the proposition in its expression is divided into two parts, because if it is mentioned in it, it is ternary, and if it is not mentioned, but supplied in the mind, then it is binary. (II 17.4-19.2)

As a marginal note explains, the objection comes from theories of the origin of language that assume that any meaning that is understood must have a corresponding expression. ${ }^{27}$ This is exactly what Quṭ al-Dinn argues against: In his

26 For a more in-depth analysis of Quṭb al-Dīn's quadripartite analysis and Jalāl al-Dīn al-Dawānī's criticism of it, see El-Rouayheb, "Does a Proposition Have Three Parts or Four? A Debate in Later Arabic Logic," 303-9 and 12-18.

27 Marginal note in MS Ketābkhāne-ye 'Āstān-e Qods 1186: "This is an objection against i) the Positor of 
view, it is not necessary that any meaning that is understood must be expressed by a corresponding simple utterance on the level of language.

Quṭb al-Din seems to think that his semantic intuitions about simple utterances also tell him something about the syntactic properties of these utterances. Just as he had explained for inflected verbs, a single utterance may signify more than one thing, as, for example, "yamshï" has the semantic value of "walking" and the syntactic property of being unsaturated. Correspondingly, whatever it is that signifies the nexus may also signify the judgment.

In the quotation above, Quṭb al-Din still seems to consider the pronoun "huwa" as a copula that is needed in ternary propositions. Shortly after, however, he quotes Avicenna and voices his discontent. Quoting from the Shïfä':

In the language of the Greeks, it is necessary to mention a temporal copula in all cases. As for the language of the Arabs, the copula may be omitted or mentioned. When it is mentioned it may be in the capacity of a name, as in "Zayd is alive (Zayd huwa hayyun)" or in the capacity of a verb, as in "Zayd was such or is such (Zayd kāna kadhā aw yakūnu kadhä)." In Arabic, it is even possible to use [the temporal copula] for something that is not temporal, like the words of "Him Exalted": "And Allah is (kāna) forgiving and compassionate." And [also] for what is not temporally specified, like when they say: "Every three is (yakūnu) odd." As for the Persian language, they don't use the proposition in which [the copula] is only imaginary. Either [it is indicated] with an expression, like their saying hast or büd, or by the vocalization, like their saying "[Someone] is such and such ([fulān] chinīna)," with kasra or fatha. (II 19.9-20.4) ${ }^{28}$

\section{Quṭb al-Dīn counters:}

language (wädi al-lugha), for [if] the parts of the proposition are four, then it must be expressed by four expressions; and ii) against the author al-Urmawī, for [Quțb al-Dīn] made him disagree with both schools of thought, since the earlier logicians thought that the parts of the proposition were three (subject, predicate and judgment), whereas the later logicians thought they were four. Ponder this!", cf. II 17.6 with note. For the science of 'ilm al-wad', see Bernard G. Weiss, "Language in Orthodox Muslim Thought: a Study of 'wad' al-lugha' and Its Development" (1966); "Ilm al-wad': An Introductory Account of a Later Muslim Philological Science," Arabica 34, no. 3 (1987); "A Theory of the Parts of Speech in Arabic (Noun, Verb and Particle): A Study in 'Ilm al-wad'," Arabica 23, no. 1 (1976); "Subject and Predicate in the Thinking of the Arabic Philologists," Journal of the American Oriental Society 105, no. 4 (1985). This rather "new" science came to be codified around Quṭb al-Dinn's time mainly by his contemporary Aḍud al-Dīn al-İjī's (d. 1355) work, especially the short al-Risāla al-waḍ 'iyya al-Aḍudiyya, recently reprinted with commentaries in Muhammad b. Aḥmad al- Dusūqī, Hạashiyat al-Dusūqĩ 'alā alWaḍiyya: Sharḥ al-Risālat al-'aḍudiyya (Lubnān: Dār Nūr al-Ṣabāḥ, 2012), 11-13.

Cf. Ibn Sīnā, al-'Ibāra min Mantiq Kitāb al-Shifầ', 37-40. 
There is an issue with what [Avicenna] transmitted about the Arabic language, for the expressions "he," "she," and "they" (huwa, hiya, humā, hum, hunna) are just pronouns and they are used when something has been mentioned before. They don't have the signification of the nexus at all, let alone the judgment-nexus. They only signify that they refer to what came before. [Thus] there is nothing signified by "huwa" (he) in the sentence "Zayd, he is alive (Zayd huwa hayyun)" except "Zayd." So how is it supposed to be a copula? (II 20.5-8)

Whatever the copula is, it was supposed to signify both the nexus and the judgment. But pronouns do not do that. Nor do hyparctic verbs, for that matter, although they do signify a nexus to an unspecified subject because they are unsaturated. On this account, the nominal sentence no longer poses a problem for Quṭb al-Din: In analogy to hyparctic verbs that signify the nexus, but not the judgment, the nominal sentence is no more incomplete than those, for the nexus is expressed by the vocalization, as Quṭb al-Dìn argues:

If you said: What is meant by it is the unconnected pronoun and the suffix pronoun (alfașl wa al-imād), then we say: The examples he adduced [... are not such], because the unconnected pronoun also does not signify for [the grammarians] the judgment-nexus; rather, [it signifies] the difference between the attribute and the predicate.

As for the hyparctic verbs, they do in fact signify the nexus; however, they do not signify the judgment, as has become clear from the [discussion of] the presenttense third person inflected verb (al-mudāari $\left.a l-g h \bar{a}^{\prime} i b\right)$, because if they did signify the judgment, then they would be susceptible to truth and falsehood. But this is not so. Moreover, considering [hyparctic verbs] copulae here contradicts what was said earlier in [the chapter on] expressions about taking [hyparctic verbs to be] different from (bi' $i z \vec{a}$ ) auxiliaries [i.e., Avicenna had said that auxiliaries and hyparctic verbs were both defective in their meaning, but that auxiliaries behaved to names as hyparctic verbs [do] to proper verbs (I 126.2ff)]. ${ }^{29}$

It is clear that what [Avicenna] takes to be a copula in Arabic is, in fact, not a copula. Rather, the copula for them [the grammarians?] is the nominative vocalization of the declension and what is analogous to it, because it signifies the meaning of being an agent [grammatical subject] (mainā al-fä́iliyya) which is [what the grammarians call] "leaning nexus" (isnād). Thus, if there is a construction of declined [elements], then the proposition is ternary, as when we say "Zayd is standing (Zaydun qua'imun)." And if [the elements are] indeclinable (min al-mubniyyāt), then the proposition is binary, as when we say: "This is Sibawayhi (hädhä Sibawayh)." That is why they say that both elements [in the latter example] are in the state of a nominative noun, pointing at the hiddenness of the copula in the soul. (II 20.12-21.7) 
This is all new. What is also new is that Qutb al-Dinn relegates the label of secundum adiacens propositions - propositions Aristotle had taken to be existential predications and that the Arabic tradition had understood as propositions without an explicitly mentioned copula - to the relatively rare cases where grammatical irregularities like the indeclinability of some nouns produce a sentence that is understood as a complete proposition with a nexus and a judgment, even though there is nothing in the expression itself that would signify either. Quṭb al-Din must have felt that his departures from Avicennan doctrine and his disagreements with his immediate predecessors warranted a summary presentation of his views to show that they are, in fact, coherent. It seems that he wrestled with these problems for a while, for we have inserted in two manuscripts (MS Dāneshgāh-e 'Arbastān 7980 and MS Ketābkhāne-ye Mellī 5-000242) a later addition by the author in which he presents his revised view:

Know that in this investigation there is a confusion (khabț) that must be pointed out. We say: When the proposition comprises three meanings, the meaning of the subject, the meaning of the predicate and the meaning of the judgment, in this case the expression is not complete unless there are three signs for the three meanings; then the proposition is ternary. And if only two meanings are signified, then the proposition is binary.

If the predicate is a verb or a derived noun, then the meaning of the predicate and of the judgment-nexus are conveyed by a single expression. As for the predicate, this is clear. As for the meaning of the judgment-nexus, this is because the verb contains the nexus of the event to a specified subject, as set out [above] in the investigation of expressions. If the subject is stated, then [the verb] positively conveys that nexus: Considering [the verb], inasmuch as it signifies the nexus of a specified predicate to the subject, it is the copula; considering it inasmuch as it signifies the event, it is the predicate. In this case the proposition is ternary, for what it means for a proposition to be ternary is just for it to have something in it that signifies the judgment-nexus. But the first or second person inflected verb, if it conveys [these] three meanings, is a ternary proposition as well.

Let it not be thought that the copula is that which signifies the judgment-nexus alone, because otherwise hyparctic verbs would not be copulae. Just as they signify the nexus, they also signify its time.

The difference between [hyparctic] and real verbs - even if they share the property of containing the nexus of a specified predicate to a specified subject - is that the real verb signifies by itself the specified predicate, unlike the hyparctic verbs, for they do not signify a specified subject or a specified predicate.

Just as the real verb, if its subject is explicitly stated, signifies the judgment-nexus, so does the hyparctic verb, if its subject and predicate are explicitly stated. And here there is no need in the connection of the predicate to the subject for the provision of a pronoun, as the

Shaykh [Avicenna] falsely assumed. Similarly, if the real verb comes after the subject, 
then there is no need for a pronoun, for on account of the mere mention of the subject the judgment-nexus is understood from [the verb]. In this case, all [three] meanings of the proposition are conveyed. [...] There is no difference between the meanings conveyed by the propositions "Got up Zayd (qāma Zayd)" and "Zayd got up (Zayd qāma)."

When the predicate is a non-derived noun (ism jāmid), if there are nominative vocalizations in the proposition, then it is ternary because [these vowel signs] signify the "leaning nexus" (isnād). This is the judgment-nexus. If there are no nominative vocalizations in [the proposition], then nothing at all in [the proposition] signifies a nexus, and it is a binary proposition.

This is what was summarized after careful reconsideration. Think about it and consider! (II 26.6-27.18; cf. note $a d$. loc.)

This passage is remarkable for several reasons. In the first paragraph Quṭ al-Din reinforces his novel position that really only rare cases that are due to grammatical irregularities like "hadha Sïbawayh" count as binary or secundum adiacens propositions. Although this may not at all be the distinction that Aristotle had intended, Quṭb al-Dìn's revision of the traditional position shows that he had a keen sense for the fact that the Arabic tradition, including Avicenna, had held onto some tenets that were considered Aristotelian and universally valid, even though they hinged on the peculiarities of Greek grammar and thus made little sense in Arabic. This revised distinction of the secundum/tertium adiacens distinction can be seen as an upshot of Quṭb al-Dīn's semantic considerations and his criticism of Avicenna's use of the copula "huwa" in the following way.

Coming from the semantic analysis of third person inflected verbs, Quṭb alDin develops a unified notion of unsaturatedness for all predicates, including those in nominal sentences. Based on his intuition that simple expressions have both semantic and syntactic values and his position that there are four conceptually distinct parts in atomic propositions, he argues that all possible predicates - real verbs, hyparctic verbs, and derived nouns (even in nominal sentences) - contain in themselves and qua simple expressions a signification of their unsaturatedness. In the case of verbs, their unsaturatedness or, in his words, the nexus to an unspecified

30 This is impossible to render in English, for contrary to English, the natural way to express a verbal sentence in Arabic is to start with the verb. When a sentence begins with a noun in Arabic, the expectation would be that what follows is a nominal sentence. "Zayd qäma" is perhaps similarly disturbing to a native speaker's sense of grammatical propriety as is "Got up Zayd." Quṭb al-Dīn's point hinges on the specificity of such grammatical propriety in Arabic, for no one would have suggested to use an artificial copula like "huwa" in verbal sentences - "qāma Zayd" is perfectly fine, and "qāma huwa Zayd" is perfectly absurd. Now, Quțb al-Dīn rightly points out that there should be no difference or, at any rate, no difference to be made up for by an artificial copula, in the logical syntax of the two sentences. 
subject, is signified by their augment; in the case of nouns in nominal sentences, their unsaturatedness is signified by their vocalization. Hence, contrary to what Avicenna had thought, there is no need to provide "huwa" in order to complete an atomic proposition. This not only makes the theory more economical, but also does away with an awkward artificiality of language that was a remnant of the Arabic translation of Aristotle's Greek. For Quṭb al-Dìn, there simply was no semantic intuition from within the Arabic language that would qualify "huwa" as a copula.

The crucial point as to why I contend that Quṭb al-Dīn penned this later addition is that the judgment, which as we have seen is signified by the same sign that signifies the mere nexus, is expressed when an unsaturated predicate is saturated by a subject expression. In other words, a proposition expresses a judgment once a value is assigned to the variables in the argument places. Remarkable here is that Quțb al-Din, based on his argument that hyparctic verbs are a distinct category of simple expressions because they do not signify by themselves a complete meaning, formulates what in modern terminology would be called the distinction between oneplaced and two-placed predicates. While real verbs have one empty argument place, hyparctic verbs are doubly unsaturated, meaning that they have two empty argument places. Filling these argument places, or assigning values to the variables, amounts to signifying the judgment-nexus: "Just as the real verb, if its subject is explicitly stated, signifies the judgment-nexus, so does the hyparctic verb, if its subject and predicate are explicitly stated." 31 The same applies to derived nouns. Even non-derived nouns in a nominal sentence work the same way. If the empty argument place signified by the vocalization is filled, then the judgment-nexus is expressed.

Given that the copula needed to signify the judgment-nexus is on Quṭb alDīn's view nothing but the syntactic property intrinsic to the semantic content of predicates when their argument place is filled, it should be clear why he thinks that there is no need to use an awkwardly artificial term like "huwa" as a third element in propositions. But then, since most propositions that consist of two simple expressions signify the three (or four, if nexus and judgment are distinguished) meanings needed for a complete atomic proposition, it makes little sense to classify atomic propositions into binary and ternary depending on whether or not and what kind of simple expression copula is used. All that remains is to acknowledge that there are certain propositions for which a semantic analysis may not identify these three meanings because of grammatical irregularities. But such cases are for grammarians to sort out, not logicians. 


\section{Conclusion}

In his Lawāmi' al-asrār, Quțb al-Dīn advances a novel theory of atomic propositions that is both more coherent and more economical than those of his predecessors. They, including his revered Avicenna, had conceived of atomic propositions as consisting of three parts - subject, predicate, and nexus - in which, depending on what type of simple expression functions as a predicate, a simple expression like "huwa" may have to be added as a copula to represent the nexus between subject and predicate on the level of language. This made for an awkward use of artificial logical language and a distinction between binary and ternary propositions that depended on whether or not and what type of copula was used. This distinction, even though meant to reflect Aristotle's distinction between secundum and tertium adiacens propositions in De interpretatione 10, was both utterly un-Aristotelian and of little use for Arabic logical theory. Quțb al-Dīn must have sensed that both the traditional preconceptions about the use of the copula inspired by an early reverential attitude toward Aristotle's Greek as a language superior to Arabic in terms of representing logical form, and the distorted binary/ternary distinction hardly useful for Arabic logical theory, were making the theory of atomic propositions unnecessarily clumsy if not outright incoherent.

After "careful consideration"32 he presents his revised views, backed by some of his semantic considerations from the first part of his commentary and by his novel quadripartite analysis of atomic propositions. The result is an analysis of atomic propositions that recognizes four conceptually distinct parts - the traditional three plus the judgment - and accounts for the copulative force that makes a combination of words or concepts into a statement with a truth-value by formulating a unified notion of unsaturatedness for all predicates. As a result of this, all predicates taken by themselves are inherently unsaturated because they signify in different ways, but by themselves and without the need for another expression signifying the copula, a nexus to an unspecified subject. All predicates also signify, once they are saturated - that is, once a subject is explicitly stated for a real verb or a noun with a case ending, or when a subject and a predicate are explicitly stated for a hyparctic verb - the judgment-nexus.

This novel account is important for several reasons. First, it shows that Quțb al-Dīn, despite his reverence for Avicenna, was prepared to go out of his way 
to criticize the Master and propose new solutions to old problems within his lemmatic commentaries. Second, it suggests that semantics and predication (haml) was an issue about which Quț al-Dīn thought hard. Future researchers will be tasked with determining the relation of this account to his other writings, from the earlier Risālat al-ma'mūla fì al-tasawwur wa-l-tașdīq to the later glosses on al-Ṭūsì's Ishārāt commentary, and the impact this novel account had on the subsequent reception history of his logical writings. They will have to established how far Quṭ al-Din's contribution relates to the enormous increase of interest in semantics and predication during the eighth/fourteenth century. ${ }^{33}$

Third, this attempt at a revised theory of atomic propositions has to be seen as a significant step toward establishing an Arabic logical theory that proceeds from an investigation of Arabic natural language to claims about logical form, as opposed to the reception and modification of essentially translated Aristotelian logic. Fourth, and connected to the latter point, Quțb al-Dīn's account of atomic propositions in his Lawāmi' al-asrār is a welcome reminder that logicians, insofar as they analyze language in order to formulate rules of logic, are to some extent bound by the language they are analyzing.

I have intentionally used Fregean terminology to describe Quṭb al-Dīn's account of the analysis of atomic propositions, because I think that his unified notion of the unsaturatedness of predicates and the dissociation of the propositional content from its judgment are close to Frege's notions of unsaturatedness and the judgment stroke. There is a parallel between the Arabic language and Frege's mathematical language in that neither uses a copula in atomic propositions. This parallel might at least partly explain the similarity of these notions. This is not to say by any means that Quṭb al-Dīn was a proto-Fregean; far from it, for Frege's point was that our intuitions about natural language deceive us about logical form, whereas Quțb al-Dīn's reasoning seems to have gone the other way. Based on intuitions about how the parts of our sentences mean, together and in isolation, he reaches the conclusion that Arabic is in perfect order. He never abandons the idea that the nexus (and the judgment-nexus) are irreducible in logical analysis, and, just like the meanings of subject and predicate, needed to be signified by some sign or other

33 For the burgeoning interest in linguistic and semantic questions, and a turn away from the technicalities of syllogistic conversion rules, in logic, paralleled in kalām and other disciplines by an increasing interest in philosophical questions, see El-Rouayheb, The development of Arabic logic (12001800), $75-80$. 
in natural language. All he abandons is the idea that such signs have to be simple expressions, for they can be part of the meaning of the predicate expression. And that is not altogether different from what Frege said. ${ }^{34}$

\section{Bibliography}

Ahmed, Asad Q. "Interpreting Avicenna: Urmawi/Tahtani and the Later Logical Tradition on Propositions." Documenti e studi sulla tradizione filosofica medievale 21 (2010): 315-42.

Al-Rahim, Ahmed H. The Creation of Philosophical Tradition: Biography and the Reception of Avicenna's Philosophy from the Eleventh to the Fourteenth Century A.D. Wiesbaden: Harrassowitz Verlag, 2018.

Aristotle. Analytica Priora Et Posteriora. Edited by W. D. Ross. Oxonii: E Typographeo Clarendoniano, 1964. , De Interpretatione = Peri Hemēneias. Edited by Hermann Weidemann. Berlin; Boston: De Gruyter, 2014.

Chatti, Saloua. "Syncategoremata in Arabic Logic, Al-Fārābī and Avicenna." History and Philosophy of Logic 35, no. 2 (2014): 1-31.

Davidson, Donald. Truth and Predication. Cambridge, MA: Harvard University Press, 2005.

al-Dusūqī, Muhammad b. Aḥmad. Hāashiat al-Dusūqĩ 'alā al-Waḍiyya: Sharh al-Risālat al-'aḍdiyya. Lebanon: Dār Nūr al-Ṣabāḥ, 2012.

El-Rouayheb, Khaled. “Arabic Logic after Avicenna." In The Cambridge Companion to Medieval Logic, edited by Catarina Dutilh Novaes and Stephen Read. Cambridge: Cambridge University Press, 2016.

"Dashtakī (d. 1498) and Dawānī (d. 1502) on the Analysis of Existential Propositions." Oriens 47, no. 3-4 (2019): 1-24.

, The Development of Arabic Logic (1200-1800). Basel: Schwabe Verlag, 2019.

"Does a Proposition Have Three Parts or Four? A Debate in Later Arabic Logic." Oriens 44, no. 3-4 (2016): 301-31.

"Post-Avicennan Logicians on the Subject Matter of Logic: Some Thirteenth- and FourteenthCentury Discussions." Arabic Sciences and Philosophy 22, no. 1 (2012): 69-90.

Elamrani-Jamal, Abdelali. Logique aristotélicienne et grammaire arabe: Étude et documents. Études Musulmanes. Paris: J. Vrin, 1983.

, "Verbe, copule, nom dérivé (fi'l, kalima, ism muštaqq) dans les commentaires arabes du Peri hermeneias d'Aristote: avec un texte inédit d'Ibn Rušd." In Studies in the History of Arabic Grammar II: Proceedings of the 2nd Symposium on the History of Arabic Grammar, Nijmegen, 27 April-1 May 1987, edited by Kees Versteegh and Michael G. Carter, 151-64. Amsterdam; Philadelphia: J. Benjamins Pub. Co., 1990.

Frege, Gottlob. Begriffsschrift, Eine der arithmetischen nachgebildete Formelsprache des reinen Denkens. Halle a. d. Saale: L. Nebert, 1879.

“Über Begriff und Gegenstand." Vierteljahrsschrift für wissenschaftliche Philosophie 16, no. 2 (1892): 192-205.

Gaskin, Richard. The Unity of the Proposition. Oxford; New York: Oxford University Press, 2008.

Hasnawi, Ahmad, and Wilfrid Hodges. “Arabic Logic up to Avicenna.” In The Cambridge Companion to Medieval Logic, edited by Catarina Dutilh Novaes and Stephen Read. Cambridge: Cambridge University Press, 2016.

34 After all, do not the brackets '( )' in $F(a)$ signify a Rāzian nexus? Don't say that we may write $F a$, for that is mere convention; you wouldn't write $\mathrm{fa}$, at least not without yet another convention. 
Ibn Sīnā, Abū 'Alī al-Ḥusayn. al-Ibāra min Mantiq Kitāb al-shifä’. Part 1, vol. 3. Cairo: Dār al-Kātib al-'Arabī, 1970.

Kalbarczyk, Alexander. Predication and Ontology: Studies and Texts on Avicennian and Post-Avicennian Readings of Aristotle's Categories. Berlin; Boston: De Gruyter, 2018.

al-Khūnajī, Afụal al-Dīn. Kashf al-asrār 'an ghawāmiḍ al-afkār. Edited by Khaled El-Rouayheb. Tehran; Berlin: Mu'assasah-'i Pizhūhishī-i Ḥikmat va Falsafah-'i Īrān; Mu'assasah-'i Muṭāla ‘āt-i Islāmī-i Dānishgāh-i Āzād-i Birlīn, 2010.

Lameer, Joep. "Ghayr al-ma'lūm yamtani' al-ḥukm 'alayhi." Oriens 42, no. 3-4 (2014): 397-453.

Menn, Stephen. "Al-Fārābīs Kitāb al-ḥurūf and His Analysis of the Senses of Being." Arabic Sciences and Philosophy 18, no. 1 (2008): 59-97.

Nuchelmans, Gabriël. Late-Scholastic and Humanist Theories of the Proposition. Verhandelingen Der Koninklijke Nederlandse Akademie Van Wetenschappen, Afd Letterkunde. Amsterdam; New York: North Holland Pub. Co., 1980.

Secundum/tertium adiacens: Vicissitudes of a Logical Distinction. Verhandelingen Der Koninklijke Nederlandse Akademie Van Wetenschappen. Amsterdam; New York: North Holland Pub. Co., 1992.

, Theories of the Proposition: Ancient and Medieval Conceptions of the Bearers of Truth and Falsity. NorthHolland Linguistic Series, vol. 8. Amsterdam: North-Holland Pub. Co., 1973.

al-Rāzī, Fakhr al-Dīn Muhamammad ibn 'Umar. Manțiq al-Mulakhkhaṣ. Tehran: Dānishgāh-i Imām Ṣādiq, 1381 AH [2002/03].

Russell, Bertrand. A Critical Exposition of the Philosophy of Leibniz. 3rd ed. Wolfeboro, NH: Longwood Press, 1989.

Shehadi, Fadlou. Metaphysics in Islamic Philosophy. Delmar, NY: Caravan Books, 1982.

al-Taḥtānī, Quṭb al-Dīn al-Rāzì. Lawāmi al-asrār fì sharḥ Maṭāit al-anwār. Edited by Abū al-Qāsim Raḥmānī. 3 vols. Tehran: Mu’assasah-i Pizhūhishī-i Ḥikmat va Falsafah-i İrān, 2014.

, Lawāmi' al-asrār fì sharḥ Mațāli' al-anwār. Edited by 'Alī Aṣghar Ja farī Valanī. Tehran: Dānishgāh-i Tihrān, 2014.

Türker, Sadik. “The Arabico-Islamic Background of al-Fārābī’s Logic.” History and Philosophy of Logic 28, no. 3 (2007): 183-255.

Weiss, Bernard G. "Language in Orthodox Muslim Thought: A Study of 'wad' al-lugha' and Its Development," 1966.

"Subject and Predicate in the Thinking of the Arabic Philologists." Journal of the American Oriental Society 105, no. 4 (1985): 605.

"A Theory of the Parts of Speech in Arabic (Noun, Verb and Particle): A Study in 'ilm al-wad'." Arabica 23, no. 1 (1976): 23-36.

, “Ilm al-wad': An Introductory Account of a Later Muslim Philological Science." Arabica 34, no. 3 (1987): 339-56.

Whitaker, C. W. A. Aristotle's De Interpretatione: Contradiction and Dialectic. Oxford, NY: Oxford University Press, 1996.

Wisnovsky, Robert. "The Nature and Scope of Arabic Philosophical Commentary in Post-Classical (ca. 11001900) Islamic Intellectual History: Some Preliminary Observations." Bulletin of the Institute of Classical Studies 47 (2004): 149-91.

Zimmermann, Fritz W. Al-Farabi's Commentary and Short Treatise on Aristotle's De Interpretatione. Classical and Medieval Logic Texts. London: Published for the British Academy by Oxford University Press, 1981. 